UDK 821.111(73)-312.4.09”1965/1994”

\title{
THE BLENDING OF FACT AND FICTION IN THREE AMERICAN DOCUMENTARY (CRIME) NARRATIVES
}

\author{
Leonora Flis
}

\begin{abstract}
The article focuses on narratives that can best be classified as documentary novels. Such narratives can frequently depict deviant crimes. The selected texts are taken from three different decades, as the study intends to determine if/how the perception of crime and, consequently, its depiction in verbal narratives change through time, and moreover, to examine the attitudes of different writers towards facts (empirical reality) that they depict. Truman Capote's In Cold Blood (1965), Norman Mailer's The Executioner's Song (1979), and John Berendt's Midnight in the Garden of Good and Evil: A Savannah Story (1994) are all instances of crime narratives that blur and thus problematize the (often thin) line between fact and fiction, and, as a result, raise issues that concern genre theory. These texts embody characteristics of journalistic, historical, (auto)biographical, and fictional accounts, and continually oscillate on the scale of factuality or fictionality.
\end{abstract}

Key words: crime novel; factuality; fictionality; documentary novel; literary journalism

\section{THEORETICAL OUTLOOK - THE DOCUMENTARY (NONFICTION) CRIME NOVEL}

In the United States, strong affinity towards nonfiction narratives, in particular towards true crime stories, has been documented since the 1960s. In his New York Times article "Murder, They Wrote" Richard Levine notes that since Truman Capote published In Cold Blood" in 1965, nonfiction books on killings have proliferated: "There has been a steady stream of best-selling nonfiction books about murder. With much 'postmodern' fiction eschewing the plot-centered pleasures of the traditional novel in favor of more self-absorbed concerns, real-life murder books have stepped in to fill a void" (1986: 90). Moreover, writers of murder narratives (not only American) generally agree that notable storytelling possibilities of real-life murders have ignited their initial interest in the genre. Many of those writers also confess that it was their reading of In Cold Blood, a story of a brutal murder of a wealthy Kansas farmer Herbert Clutter, his wife and two

\footnotetext{
${ }^{1}$ The book was translated into Slovene already in 1967 by Maila Golob; the Slovene title reads Hladnokrvno.
} 
of their children, that first showed them how techniques of fiction could be used to tell true stories about real people.

The term "nonfiction novel" was not given wide recognition (in fact, it hardly existed within the canon of literary terms), until Capote confidently bestowed this classification on his work In Cold Blood. The 135,000-word story first ran in parts in four consecutive issues of The New Yorker, beginning with September 25, 1965 issue. When Random House published it in the book form as In Cold Blood, it signified the arrival of a new form called the nonfiction novel. ${ }^{2}$ Another term, describing the same literary phenomenon/genre, has gradually made its way into literary studies' terminology database - the documentary novel. ${ }^{3}$

Documentary crime novels should not be equated with crime fiction that has no reference to real-life events. They differ from historical accounts as well, namely, in their application of novelistic techniques and clearly noticeable aesthetic emplotment (structuring) of the depicted events. However, we should certainly not overlook the resemblance between documentary novels and texts that are classified as literary journalism. Let us recall that initially literary journalism ${ }^{4}$ was termed New Journalism ${ }^{5}$ and New Journal-

${ }^{2}$ Capote went to great lengths when he was "preparing the ground" for his novel. His diligence is truly hard to match and many writers of nonfiction novels do not pay as much attention to the tiniest of details as Capote did. The composing of In Cold Blood was in progress between November 1959 and April 1965. During that time, Capote's energies were almost exclusively devoted to the investigating of the murder of the Clutter family from Kansas. He collected enough notes to fill a small room, and then carefully sifted through them. His research amounted to about six thousand pages of interviews, including extensive testimony from the killers themselves. It took an immense, devastating emotional toll on the author. In one of the interviews, after the book's publication, Capote said the following: "If I had know what that book was going to cost in every conceivable way, emotionally, I never would have started it, and I really mean that" (Reed 1981: 31; originally taken from the article/interview "Literary Horizons-The Story of an American Tragedy," Saturday Review, 22 Jan 1966: 37).

${ }^{3}$ There are many terminological inconsistencies when it comes to the phenomenon of the nonfiction or documentary novel. Some scholars prefer the term faction. Alex Haley came up with this term for his work Roots (1976). He called the book faction, denoting a fusion of fact and fiction. Some point to close resemblance between the nonfiction novel and historiographic metafiction (e.g. Linda Hutcheon, who sees as the main point of congruence between the two narratives their inclination towards metafictionality and provisionality). In Latin America, the term testimonio novel appeared, for example. Finally, there are studies which simply see the documentary novel as an example of a historical narrative. Nancy Pedri in her dissertation Factual Matters: Visual Evidence in Documentary Fiction (2001) puts an equation between New Journalism, literary journalism, and the documentary novel (57). Moreover, John Hellmann (Fables of Fact: The New Journalism as New Fiction, 1981), sees the new type of journalistic writing as "an important response to the dislocations of the contemporary American experience" (ix), and believes that the terms nonfiction novel and New Journalism can be used synonymously, as they denote one and the same phenomenon. Slovenian scholar and journalist Sonja Merljak Zdovc in her dissertation on Tom Wolfe and New Journalism understands the nonfiction novel as a subcategory of literary journalism. She divides the latter into narrative journalism and nonfiction novels. She points out the difference between texts that are published like journalism articles in magazines and newspapers and texts published in a book form. Both is literary journalism, but the texts differ in terms of length and the writers' research methodology (Merljak Zdovc 2004: 9).

${ }^{4}$ Literary journalism is a term that is broader in regard to its temporal aspect, if compared to the term New Journalism. It denotes the same journalistic-literary phenomenon, but it is not limited solely to the texts created in the 1960s and the early 1970s in the United States.

${ }^{5}$ Tom Wolfe, whose name is normally used in reference to New Journalism's birth, reports the following in the anthology The New Journalism (1973), which he co-edited with E.W. Johnson: "In the early 1960s, a curious notion, just hot enough to inflame the ego, had begun to intrude into the tiny confines of the feature statusphere. It was in the nature of a discovery. This discovery, modest at first, humble in fact, deferential, 
ism has the same re-emergence point ${ }^{6}$ as the documentary novel - the 1960s. In addition to temporal synchronicity, the method of using truth-claims and mixing them with the subjective, interpretative approach represents a significant point of congruence between literary journalism and the documentary novel. Nevertheless, while the documentary novel allows fluctuation between imagination and documentary data, literary journalism claims to stay strictly within the reign of truth. Another noteworthy characteristic of a documentary crime narrative is also the fact that the reader usually knows some of the facts in advance. Normally, these facts are limited to the information that is available to the public through the mass media. Kenneth Reed calls this characteristic a kind of "dramatic irony where the reader is mostly aware of the crime and the perpetrators" (1981: 113). (This can well happen with literary journalism as well, as there may be, due to writing strategies that differ from conventional journalism, a substantial lag between the publication of literary journalism articles and other - immediate - reports in the media on a specific event.)

Documentary novelists are inclined to treat historical data as working material without being burdened with the presupposition of its fixed, unchangeable, or ultimate nature. Such awareness of the representational nature of history, of its dependence on the ways of fiction is not only a characteristic of novelistic writings but also of literary journalism. However, as previously observed, a literary journalist is, at least in theory, dedicated to presenting the truth. He should not succumb to inventing, but selection and interpretation (emplotment) undoubtedly still take place. As John Scaggs notes, "no telling or repetition of history is pure fact, free of individual perception, interpretation, or selection" (2005: 123). In fact, a historical record in itself is a discursive entity, offering "a re-presented, thoroughly selective account of what actually happened" (Cobley 2003: 30).

Like a (literary) journalist, a documentary novelist depends on documentary data, but simultaneously, he possesses greater narrative freedom and has the ability to manipulate the facts and thus gain control over the shock and the scandal his writing depicts; he can more freely shape the formlessness and the ambiguities of the past and the present in accordance with his own desires. In Matters of Fact: Reading Nonfiction Over the Edge, Daniel W. Lehman states that "nonfiction can produce both a disquieting effect and a promise of formal control that releases that anxiety" (1997: 121). Nonetheless, the documentary novel is a narrative in which the documents or the truth-claims

you might say, was that it just might be possible to write journalism that would ... read like a novel. Like a novel, if you get the picture. This was the sincerest form of homage to the Novel and to those greats, the novelist, of course" (9). Furthermore, Wolfe explained that he had no idea who had coined the term new journalism, or even when it was coined. He writes: "Seymour Krim tells me that he first heard it used in 1965 when he was editor of Nugget and Pete Hamill called him and said he wanted to write an article called 'the New Journalism' about people like Jimmy Breslin and Gay Talese. It was late in 1966 when you first started hearing people talk about 'the New Journalism' in conversation, as best as I can remember. I don't know for sure. [...] To tell the truth, I've never even liked the term. Any movement, group, party, program, philosophy or theory that goes under a name with 'New' in it is just beginning for trouble. [...] New journalism was no movement. There were no manifestos, clubs, salons, cliques; not even a saloon where the faithful gathered. At the time, one was aware only that all of a sudden there was some sort of artistic excitement in journalism, and that was a new thing in itself" (23).

${ }^{6}$ The stories that combine facts and imagination are hardly a new phenomenon, and have a considerable past in the history of Anglo-American literature - Defoe, Dickens, Twain, and later, Dreiser, Dos Passos, Doctorow, and Styron could well fit this profile. 
that it introduces retain an undeniable connection to extratextual reality, and hence the narrative requires its readers to adopt a set of reading conventions that differ from those used in reading fictional texts. In her dissertation Factual Matters: Visual Evidence in Documentary Fiction, Nancy Pedri observes that "documentary fiction asks readers repeatedly to shift referential criteria from the internal coherence of the fictional text to the external correspondence with the factual world; in this way, its truth-claims are asserted" (2001: 5).

Novelization or subjectivization of literary journalism as well as journalization or objectivization of the novel can both be interpreted as essential characteristics of the sort of narrative evolution that Mikhail Bakhtin talks about when discussing the fluid and indeterminable nature of the novel. In Dialogic Imagination he notes that from the very beginning the novel occupied the zone of "direct contact with inconclusive presentday reality" (1981: 39). Personal experience and free creative imagination lie at its core. Bakhtin views the novel as a literary form that is completely free, non-canonical, and constantly changing and finding new expressive means. John Hartsock in A History of American Literary Journalism (2000) therefore talks of the "Bakhtian novel," as a narrative form that stands in opposition to the traditional canonical novel. Bakhtin, in a way, transported Einstein and his relativity theory into the literary realm and thus aestheticized relativity. "By directing relativity into the aesthetic, Bakhtin ushered the literary universe into the twentieth century" (Stone 416).

As pointed out, the documentary novel has a fluctuating nature. It oscillates between life-writing on the one hand (memoirs, auto-biographical texts, travel narratives, historical texts, as well as journalism), and fiction narratives on the other hand (texts ranging from realistic to postmodernistic). It is a dual (bi-referential) narrative; it is, as Mas'ud Zavarzadeh puts it in The Mythopoeic Reality: Postwar American Nonfiction Novel, an enactment of a "yes-and-no situation" (1976: 227). As opposed to the modernist poetics, which does not support oscillation between life and art, or the existence of the fictional and the factual within the same work (such vacillation is regarded as a sign of lack of artistic control), the postmodern approach allows the existence of two fields of reference within one single text, namely, the internal world of the narrative, "which enjoys the aesthetic control of the verbal arts in general," and the external reality with its experiential aspect, "which possesses the authority of reality" (Zavarzadeh 1976: 77). I believe that appreciating truth-claims and narrative strategies used in documentary fiction, requires a line of reasoning and a way of reading that is not restricted to either fictional or nonfictional generic contract. A special contractual relationship between the writer and the reader regarding the narrative's truthfulness or lack of it needs to be established.

\section{ON THE PRACTICAL SIDE}

In Capote's (In Cold Blood), Mailer's (The Executioner's Song ${ }^{7}$ ), and Berendt's (Midnight in the Garden of Good and Evil ${ }^{8}$ ) narratives - which all revolve around crime/

\footnotetext{
${ }^{7}$ The book was translated into Slovene by Ana Padovan in 1982; the Slovene title is Krvnikova pesem.

${ }^{8}$ The novel has not been translated into Slovene yet.
} 
murder - we observe specific constitutive domains that we associate with fiction (e.g. domains of characters, events, points of view and time). However, the large quantity of truth-claims in their accounts obliges the reader to interpret the position of these narrative hybrids (or factions) vis-à-vis alternative (real) world constructions. Their texts openly lay claims to the actual world. There is a difference, though, between Capote, on the one hand, and Mailer and Berendt, on the other. While Mailer and Berendt admitted the presence of the fictional component in their narratives, Capote maintained his claim of having recreated the Kansas murders with complete accuracy. Yet all three texts display a fuzzy or transitory line between the fictional and the nonfictional. It often happens that readers (for simple reasons of convenience, such as stacking books at a library or in one's own home, for instance) draw the divides themselves, and thus (seemingly) avoid narrative ambiguity. In order to shun such forced classification, we can simply view a particular hybrid narrative as an instance of syncretic discourse that is marked by constant (generic) oscillation and accept it as such.

Postmodern documentary novelists (and usually their readers as well) know that there is no final truth, no definitive answer, hence they do not assume that they can give (or get) one. Generally, both the narrator and the reader are aware of the unreliability of the verbal traces of empirical reality in the narrative. They are aware of the fact (explained in great detail in Paul Ricoeur's Time and Narrative, 1983-85, for example) that the activity of producing a verbal representation of some part of the past in a text is always rhetorical, and therefore interpretative. This is the principal philosophy or strategy of narrating in The Executioner's Song (1979) as well as in Midnight in the Garden of Good and Evil (1994). Faithful representations of factual evidence are always coupled with assertions that attest to the prominent role of subjectivity in organizing, understanding, and imposing meaning on them. Nancy Pedri explicates: "The joining of the nonfictional with the fictional highlights not only their differences, but also their collaboration in the attainment of truth - a truth that is necessarily factual and poetic" (2001: 48, 49).

In the Afterword to The Executioner's Song, Mailer made it clear that he had tried his best to give a factual account of the selected events, but, at the same time, he also stated that he had told the story of the killer Gary Gilmore ${ }^{9}$ as though it were a novel. He tried to tell the story as accurately as he could, but "that does not mean it has come any closer to the truth than the recollections of the witnesses" (The Executioner's Song, 1051). In a live online interview for Bill Thompson's show EyeOnBooks,$^{10} \mathrm{John}$ Berendt stressed that in Midnight he had assumed certain story-telling liberties, used pseudonyms, and changed the timing of the events a bit, which, as he admitted, caused some confusion, especially because of a note on the cover of the book classifying Midnight as a work of nonfiction. He, like Mailer, did not attempt to compose a completely accurate picture of the Savannah events, for Berendt is well aware that we only learn about the

\footnotetext{
${ }^{9}$ Gary Gilmore robbed and murdered Max Jensen, a Sinclair gas station employee in Orem, Utah on July 19, 1976. The next evening, he robbed and murdered Bennie Bushnell, a motel manager in Provo. Gilmore was the first man to be executed after the U. S. Supreme Court reinstated the death penalty in 1976 . He refused all appeals to which he was legally entitled.

${ }^{10}$ Listen to Bill Thompson's interview, Bill Thompson's Eye on Books, 2006. 3 May $2008<\mathrm{http}: / / w w w$. eyeonbooks.com/ibphp?ISBN=1594200580>.
} 
past thorough textualized remains, and they in themselves are incomplete, fragmentary and, in many cases, deeply subjective (diaries, memoirs, letters, ...).

With his journalistic reports as well as longer narratives, Mailer gained a reputation for being a lucid critic of the national scene and a prophetic national commentator. In The Executioner's Song, he showed that he could be such an observer without the personal references that characterize most of his earlier nonfiction (including the Pulitzer Prize winning book The Armies of the Night, 1968). Moreover, he was convinced that there is no history without nuance. ${ }^{11}$ The concern for nuance and the rejection of fact underlie Mailer's "engaged reportage, a literary form closer to the novel than traditional journalism" (Merrill 1992: 84). It was the novel that Mailer considered as genre par excellence, and he more or less consistently insisted on the pre-eminence of his novelistic mission. He argued at every opportunity that his longer nonfiction accounts should not be confused with factual journalism. ${ }^{12}$

Mailer had a notable tendency to sneak into his stories, to become a literary character, a part of the narrative (narrated) world. However, in his book on Gary Gilmore's murders, he sets himself aside; not by putting up a mask, but by feeling his way into the minds of his characters. In an interview in 1981, Mailer stated that he was not as interesting to himself as he used to be and that was supposedly one of the reasons why he omitted his immediate presence from the narratives (Dickstein 2002: 160). What is more, to write about Gilmore in Mailer's usual style would have risked the accusation of inflating Gilmore rhetorically; the nature of the story required a faster narrative movement than many of Mailer's earlier books. Mailer felt very humble in the face of his mysterious materials and did not think he had "the right to generalize" (Merrill 1992: 157). In other words, in The Executioner's Song Mailer as the author disappeared, so that the book could appear.

John Berendt's documentary novel is a first person narrative that has clear lyrical undertones and at times displays characteristics of gothic novels. Parts of Midnight can read like a true crime story, other times, Berendt's book - which is a collection of crazy people, cranks, and eccentrics - is reminiscent of a travelogue. Berendt's account, which became especially popular after the release of the movie in 1997 with the same title (directed by Clint Eastwoood), would best be described as postmodern kind of bricolage, a syncretic narrative with frequent chapter breaks and a series of plots with many digressions. This true-crime tale that ignores traditional genre conventions is a

\footnotetext{
${ }^{11}$ In Miami and the Siege of Chicago: An Informal History of the Republican and Democratic Conventions of 1968 (1968), Mailer quotes a New York Times article on a demonstration (confrontation between white Republican delegates and black demonstrators in the Miami Beach's Fontainebleau Hotel) that he too was supposed to report about but he missed it, because he was in a restaurant. The Times report briefly mentioned "two white girls dressed in red and blue tights" who sang 'When Ronnie Reagan comes marching in'. But they couldn't interrupt the black protesters. Their leader shouted: "I may be black, but I am somebody. I may be poor, but I am somebody." Mailer regrets the fact that he missed the protests, but he also poses certain questions about the NY Times report: "Were the Reagan girls livid or triumphant? Were the Negro demonstrators dignified or raucous or self-satisfied?" He could not find those answers in the Times report and so he states: "It was a good story but the Times was not ready to encourage its reporters in the thought that there is no history without nuance" (see Frank Rich's article "How to Cover an Election," The New York Review of Books, 2008. 5 Oct 2009 <http://www.nybooks.com/articles/21411>).

${ }^{12}$ For a detailed account on Mailer's view on the novel, see J. Michael Lennon's introductory study in the book Critical Essays on Norman Mailer (1986).
} 
saga of an antiques dealer Jim Williams, who in 1981 shot his lover Danny Hansford in the historic Mercer House in Savannah. The murder as well as William's own (somewhat mysterious) death have been obsessing the Savannahians ever since. In Berendt's narrative, Jim Williams's life and death become a biography, a detective story, and a courtroom drama; fact and fiction effectively blend into multimodal faction.

Capote, on the other hand, still appeared to believe in the absolutist picture of the totalising reality at a time when the notions of fragmentation and decentralisation were flooding the practical and theoretical aspects of narrative discourse. For many critics In Cold Blood has presented the aesthetic and moral problems inherent in the task of representing empirical reality on the page. Reading Capote's own comments on what he wished to achieve in In Cold Blood in light of Derrida's shift away from linguistic stability (by declaring the connections between language and reality as arbitrary) ${ }^{13}$, makes the writer look almost reactionary. The key problematic aspect of In Cold Blood seems to be Capote's somewhat presumptuous claim that he had written a totally accurate account of events. Mailer never claimed that, nor has Berendt. In essence, Capote was striving for truth but facts got in the way.

By way of documentation and insertion of verifiable facts (names of persons, cities, hotels, etc.), Capote (in the vein of literary journalism) authenticates his narrative. Yet his account constantly displays the (bi-referential) tension between the factual and the fictional. Capote managed to capture the ambiguous (sometimes fiction-like) dimensions of the Kansas (Holcomb) reality well, especially loopholes in the legal system that concern capital punishment. Through dialogues, letters and testimonies, medical and legal documents that Capote diligently recounts, his narrative shows how equivocal judgements of truth and morality can be, how dependent truth is on a personal, subjectivized vision of reality, and how close to fiction it can be at times. In addition, even though Capote tried hard not to appear in the narrative, we can feel his somewhat biased stance on the Kansas tragedy. Capote places most of his attention on Perry Smith and structures his narrative around him. The writer's relationship with Perry was a rather personal one. Capote's lifelong friend, writer Harper Lee, explained that "every time Truman looked at Perry he saw his own childhood of disaffection and rejection" (De Bellis 1979: 534). That particularly influenced the story and caused the occurrence of mimetic lapses; the most serious discrepancies in the book are in one way or another connected with Perry Smith. A troubling deviation from the truth is for instance Capote's claim how Smith's last words were "I apologize," although none of the other reporters, editors, or wire-service representatives were able to confirm this claim.

Here are Smith's last words, as recorded in In Cold Blood:

I think it's a helluva thing to take a life in this manner. I don't believe in capital punishment, morally or legally. Maybe I had something to contribute, something. [...] It would be meaningless to apologize for what I did. Even inappropriate. But I do. I apologize (406).

\footnotetext{
${ }^{13}$ Derrida sees language as a fluid system dependent upon internal self-reference. The linguistic instability that he refers to in fact extends to him challenging general theology - he suggests that the universe of meanings is not governed by an organizing force (logos) but rather by critical uncertainty and instability of meaning. See also Hugh Rayment-Pickard's Impossible God: Derrida's Theology, 2003.
} 
The reader cannot or should not avoid noting such deviations from strictly factual mimesis (which the author claimed to have applied in full). Capote also changed certain personal names (this, however, could possibly be justified with ethical as well as legal concerns), and, even more importantly, there is the concluding cathartic graveyard scene that in reality never happened (the book's ending has frequently been described as somewhat cheap and sentimental). ${ }^{14}$

Zavarzadeh states that narrative omniscience in nonfiction novels is not such as one would normally find in works of fiction. The "documentary omniscience" is limited, or "empirical," in Zavarzadeh's terms (1976: 77). This denotes knowledge gained through research, and therefore it somewhat differs from the scope (nature) of the information the fiction novelist works with. However, Capote with his narrative stance sometimes transgresses the borders of the documentary novel, for he occasionally behaves like a know-it-all, God-like omniscient narrator in a traditional (realistic) fictional narrative. Even though Capote's tone tries to stay even and the New Yorker-ish detachment is certainly present, the writer could not distance himself entirely from the narrative. It seems erroneous to claim, as Jorge Luis Borges did, that In Cold Blood is "composed with an almost inhuman objectivity" (Zavarzadeh: 42). As much as Capote's omniscient narrator wants to stay out of the narrative and predominantly rely on research and factual data, he fails at times, because of the author's strong need to aestheticise, to reach a desired conclusion (a cathartic end).

Mailer in The Executioner's Song, on the other hand, achieved his (documentary) (semi)omniscience through the third-person narrative stance. Mailer managed to adopt a style of writing that was different from the usual insertion of his large ego into his tales. He kept his ego out of the story when writing about the psychotic Gary Gilmore, in order to go for the "great weight, mystery, and dignity of fact," as he explained (Beard 1985: 144). The result is an elaborate collage of scenes; it seems nothing at all is left out (nothing that actually happened, that is). Mailer did not come across the story until after it was over, and with the exception of his own interviews with surviving relatives and friends of Gary Gilmore, he was personally not involved in the Gilmore case. He does not pick only one character and follow him or her around for the duration of the book, as is customary for a typical figural narrative perspective. ${ }^{15}$ Instead, Mailer constantly

\footnotetext{
${ }^{14}$ Many critics, literary scholars, as well as (amateur) readers have agreed that part four (last section) of Capote's book lacks the suspense of the other chapters because it is weighted down with too many details on the justice system and extraneous stories of other prisoners and their crimes. Furthermore, the concluding pages, like an old-fashioned novel, provide closure with information about various marriages, births, deaths, and other changes in the lives of all who played a part in the story. As proof of Capote's "condensation" of events, or rather, his emplotment of the narrative, Merrill lists the following features of the text: the regular alternation of sections dealing with the killers and their victims-to-be, the authorial comments, whereby Capote points up the impending catastrophe (Mr. Clutter heads home for the day's work "unaware that it would be his last"), the almost-complete suppression of Capote's role in the later events, and the relative brevity of his narrative, "which condenses 8000 pages of material into a book one-third the length of The Executioner's Song" (1992: 156). A different perspective is offered by John Hartsock - he interprets In Cold Blood as literary journalism. He makes a brief note on the invented scenes (which he does recognize as problematic): "Such are the temptations of a gorgeously affirmed subjectivity that slips into its own invention, and undoubtedly this will continue to be a problem that periodically surfaces in narrative literary journalism" (2000: 198).

${ }^{15}$ We talk about figural perspective when the story is told through the eyes of a third-person internal focaliser. The most typical examples of this narrative perspective are Franz Kafka's and Henry James's
} 
shifts his perspective from one character to another, reports everything that a specific character sees and experiences, thus providing an elaborate picture of the given reality, composed of a multitude of individual views and visions.

The story is told by unidentified narrators who express their perspectives through a large cast of characters. The narrators "range freely in time and space, and knit several plot strands into a tremendous social tapestry" (Lennon 1986: 16). The real, the documentary for Mailer is precisely the hundreds of subjective accounts from which to build the story. Unlike Capote, Mailer does not construct the interpretation of events; instead, he offers what is made to seem like all the facts (limited omniscience), i.e., all the versions or interpretations of the events he describes.

Furthermore, by presenting each event from the point of view of a participant, the writer ensures that the texture of each episode resembles that of a novel. Mailer himself called the book a novel, because he was convinced it reads like one and he was right. He was working with a massive accumulation of second-hand information which can only be as accurate as the statements of the people who reported it, as Mailer himself expressed. ${ }^{16}$ In fact, Mailer was convinced that absolute truth cannot be conveyed through any medium, as it does not exist. In a lecture at the University of Texas in Austin in 2006 he stated that "one cannot arrive at the truth; what one can arrive at is the semblance of the truth." "The core of my belief is that the style you use when writing a book, the mode you use when writing a book, makes it fiction or nonfiction." ${ }^{\prime 17}$

A similar view on portraying reality can be found in John Berendt's book. Before Berendt embarked on his journey to and through Savannah to compose Midnight in the Garden of Good and Evil, he had already had 25 years' experience as a journalist, including editing New York Magazine and writing a column for Esquire. According to the author's own words, he wanted to write a true story that reads like fiction. However, in an interview with Michael Sims in August 1997, Berendt defined Midnight in the Garden of Good and Evil as a work of nonfiction: "It's a nonfiction novel. It's got elements of travel, true crime, novel, all those things. Bookstores would have been sorely pressed to figure out where to put it. But fortunately they can put it on the bestseller shelves for now." 18

Berendt wanted to give his story a momentum; the book needed to have a rhythm of action, a distinct development arch. As an involved narrator, Berendt wanted to create pictures in the reader's mind that are constantly changing, developing, moving. The author skillfully interweaves an entertaining first-person account of life in this isolated remnant of the Old South with the unpredictable twists and turns of a landmark murder case. The book, which clearly displays the author's "storytelling liberties," reads like a novel and the readers have many times wondered where the truth ends and fiction begins. In terms of genre, the best way to describe Midnight would be to label it a generically fluid narrative. Even though the narrative draws on traditional themes found

texts; we can observe the same practice in The Executioner's Song, but Mailer's narrative is unique in its usage of multiple focalisers.

${ }^{16}$ See The Executioner's Song, 1051.

${ }^{17}$ See Alex Au, "Novelist Mailer Says Truth Hard to Portray," The Daily Texan Online 13 Nov 2006. 1 Oct 2009. <http://www.dailytexanonline.com/2.4489/novelist-mailer-says-truth-hard-to-portray-1.963464 >.

${ }^{18}$ See Michael Sims, "We Check in With John Berendt," BookPage.com Aug 1997. 29 Jan 2007 <http:// www.bookpage.com/9708bp/firstperson1.html>. 
in William Faulkner, Flannery O'Connor, William Styron, and Alice Walker (namely, grotesque characters, gothic settings, North/South clashes, emblematic southern heroes and belles, racial ambiguities, etc.), it provides a typical postmodern generic hybridity: it joins together travel narrative, tourist brochure, detective fiction, (auto)biography, and a courtroom drama.

This is how Berendt expresses his intentions at the end of the second chapter titled "Destination Unknown":

An idea was beginning to take shape in my mind, a variation of my city-hopping weekends. I would make Savannah my second home. [...] I would inquire, observe and poke around wherever my curiosity led me or wherever I was invited. I would presume nothing. I would take notes (37).

Berendt's narrator often engages in self-reflexive questioning of documentation available to him and expects the reader to do the same. He is aware of the unreliability or instability of facts. However, the writer still needs to assure the reader that, despite the presence of different points of view and the element of subjective interpretation, he tries to describe the story as accurately as possible (Berendt does that by using court records, letters, and statements of witnesses, for example). Pedri observes that "only when the acknowledgements of multiple interpretations are accompanied by a faithful depiction of the document is there the creation of an aesthetic space where the reader is encouraged to take on the challenging role of interpreter" (2001: 64). For only in this manner "the interpretative acts of the narrator who passes judgment on the document's historical validity actually secure its referential frame for the reader" (Pedri 2001: 65).

Lastly, we need to point out the importance of plotting or emplotment (as a structural principle) in documentary crime novels. Intentional plotting is undoubtedly an apparent characteristic of documentary novels. The acts of selection and emplotment (i.e., the synthesizing of heterogeneous experiences into an intelligible whole), give a nonfiction text an aesthetic dimension. Closure, which is definitely an indispensable part of the narrative plot, probably represents one of the more problematic components of the documentary novel's design. As we have observed, Capote's novel surely transcended the conventions of journalism, since the writing has a structure which is a result of an aesthetic conception. A similar tendency is found in Mailer and in Berendt. Yet none of the selected books should be viewed as conventional fiction narratives, be they murder mystery novels, crime novels, or conspiracy tales.

When analyzing Capote's narrative, we observe that he applied a narrative technique or strategy that is supportive of the randomness of events that the book emphasizes. Capote focuses on the mysterious, elusive nature of the Holcomb murders and their consequences, yet, at the same time, the author tries to impose some sort of order on the puzzling reality. John Hollowell in "In Cold Blood: The Search for Meaningful Design" (1997) explores in detail the design of the book, which is, in his opinion, drawn to a large degree from detective Dewey's verbal world, because it strategically offers an explanatory framework for understanding the murders. ${ }^{19}$ Dewey acts as the central intelligence, guiding the reader's integration of plot elements. "Dewey's role is

${ }^{19}$ John Hollowell's essay was published in Arizona Quarterly, Autumn 1997: 97-115. 
critical," states Hollowell, "since his motives and desires allow readers to identify with the eventual capture and punishment of the suspects" (2). The scenes of the reconstruction of the murder, the confession, the trial, and of the execution (as mysterious and baffling as they look at times) are carefully constructed and divided in four major sections. Moreover, Capote inserts a redemptive ending and that imposes additional (and artificial) order on the narrative.

The Executioner's Song is a truly massive and macabre chronicle of life and death of Utah murderer Gary Gilmore. Mailer carefully edited and structured his text, but, as opposed to In Cold Blood, The Executioner's Song does not give any real closure or comprehensive conclusion about Gilmore's motives or drive behind his destructive force. The book is divided in two large sections (each subdivided into seven parts): Book One - Western voices, and Book Two - Eastern Voices. Together they make up a narrative comprised of forty-four chapters (each titled). The two sections are symmetrical in terms of structure and also of approximately the same length. The first book focuses on Gilmore's life after his release from prison, ${ }^{20}$ his relationship with Nicole Baker, and the two murders he committed. The second part details the publicizing of the story and Gilmore's execution. Gilmore's psychosis and personal agonies described in Book One are echoed in (equally agonizing) public spectacle in Book Two. Mailer utilizes Gilmore to express his paranoid view of history as a system and to point to a frequently distressing and frustrating relation between private and public life in the United States. ${ }^{21}$

Unlike Capote, Mailer does not strive to console or fool the reader with a cathartic ending. In fact, the book ends with the description of a resigned Gilmore's mother, Bessy, who is ready to die herself: "If they want to shoot me, I have the same kind of guts Gary has" (1049). Mailer wants to stress that certain things or events in life, such as death and crime, for instance, are many times incomprehensible. Even the neat structure of the narrative that offers exceptionally detailed descriptions of all the major players in the story, as well as of the trial and its aftermath cannot completely unmask Gilmore and explain the numerous contradictions in him and the real motives behind his crimes. The reader is the one who is supposed to form his/ her own opinion on Gilmore and "judge" him accordingly.

As for John Berendt, he does not follow the actual sequence of events as diligently and in such detail as Mailer does, but he does, nevertheless, structure his narrative into a more or less cohesive whole. Berendt admits that he partly changed temporal ordering, because he wanted to make the story more dramatic. He aestheticizes, novelizes his account of the Savannah murder and he does not want to give a final or definitive resolution regarding the real motive behind Danny Hansford's murder. Moreover, he deliberately gives the death of Jim Williams an air of mystery. Midnight in the Garden of Good and Evil more closely than the other two accounts resembles a (postmodern) mystery crime story.

In theory, the documentary novelist is not supposed to change or modify the plot in order to convey his own private vision through it. Zavarzadeh, for instance, is of the

\footnotetext{
${ }^{20}$ Gary Gilmore spent eighteen out of twenty-two years between ages thirteen and thirty-five in prison for various offences and violations.

${ }^{21}$ For further reading on different dimensions of Gilmore's role in The Executioner's Song, see Patrick O'Donnel's book Latent Destinies: Cultural Paranoia and Contemporary U.S. Narrative, 2000: 115.
} 
opinion that we can only talk about a "plot" in the nonfiction novel if we choose "to describe the unfolding events of our own human lives as a cosmic 'plot,' designed to bring out some metaphysical meaning" (1976: 80). Practical examples, however, reveal elaborate, many times very intimately conditioned emplotment moves (selection and interpretation), propelled by the authors themselves and not only by some universal order of events in human lives. This is something that would not be acceptable in journalistic writings and clearly points to the difference between literary journalism and documentary novelism (especially the kind with an accentuated postmodernistic base).

In postmodern times, the rejection of the concepts of consistency, logocentrism, and determinable meaning denotes a move away from excessively constraining rational and aesthetic systems, whether of classical realism or modernism. What we have noticed in all the narratives discussed is that the subjectivity of the interpretative act in a way clashes with the neutrality and objectivity normally associated with factual narration and historical research. However, many contemporary (postmodern) historians as well as literary scholars agree that history and historiography are many times more a form of art than a strictly factual discourse. Moreover, postmodern documentary (true-crime) narratives normally do not aspire to be determinable in their presentation of reality; the authors questions certainties about the self, the mind, and the ambient world. The detective-centered (moral and intellectual) authority is usually lost as well. Especially Mailer and Berendt write along those lines. If compared to Capote, they seem to be less selective, more inclined to amass the cases they describe than to shape them toward a single conclusion. What is more, they do not introduce a detective (or some other authoritative figure) who would guide the reader and be the source of unquestionable truths about the crimes. Capote, on the other hand, attempts to give his text a cathartic ending and his detective Dewey plays a crucial part in bringing the narrative to that point. The more we move into the postmodern, the more the superior or definitive explanatory framework in the narratives fades away. Such discourses openly raise questions about the nature of reality and the limits of knowledge. The final reasoning on the crimes and the motives behind them thus seems to be left to the reader.

Ljubljana, Slovenia

\section{WORKS CITED}

Au, Alex. "Novelist Mailer Says Truth Hard to Portray." The Daily Texan Online 13 Nov 2006. 1 Oct. $2009<$ http://www.dailytexanonline.com/2.4489/novelist-mailer-says-truth- hard-to-portray$1.963464>$.

Bakhtin, M.M. The Dialogic Imagination: Four Essays. Trans. Vadim Liapunov and Kenneth Brostrom. Austin: U of Texas P, 1981.

Beard, John. "Inside the Whale: A Critical Study of New Journalism and the Nonfiction Novel." Diss. The Florida State U, 1985.

Berendt, John. Midnight in the Garden of Good and Evil: a Savannah Story. London: Vintage, 1997. 
Capote, Truman. In Cold Blood: a True Account of a Multiple Murder and its Consequences. New York: Random House, 1965.

Clark, Roy Peter. "The Line Between Fact and Fiction”. Creative Nonfiction 16, Pittsburgh: Creative Nonfiction Foundation, (2000): 4-15.

Cobley, Paul. Narrative. The New Critical Idiom. London \& New York: Routledge, 2003.

De Bellis, Jack. "Visions and Revisions: Truman Capote's In Cold Blood". Journal of Modern Literature 7.3 (1979): 519-537.

Derrida, Jacques. "Signature Event Context”. Limited Inc. Trans. Jeffrey Mehlman and Samuel Weber. Evanston: Northwestern UP, (1988): 1-25.

Dickstein, Morris. Leopards in the Temple: The Transformations of American Fiction, 1945-1970. Cambridge (MA) \& London: Harvard UP, 2002.

Hartsock, John C. A History of American Literary Journalism. Amherst: U of Massachusetts P, 2000.

Hellmann, John. Fables of Fact: The New Journalism as New Fiction. Urbana: U of Illinois P, 1981.

Hollowell, John. Fact and Fiction: The New Journalism and the Nonfiction Novel. Chapel Hill: U of North Carolina P, 1977.

"In Cold Blood: The Search for Meaningful Design." Arizona Quarterly, 53.3 (1997): 97115.

Juncker, Clare. "Simulacrum Savannah: Midnight in the Garden of Good and Evil". Literature Film Quarterly, 1 Jan. 2005. 15 Jun. 2008 <http://findarticles.com/p/articles/mi_qa3768/is_200501/ ai_n15348542>.

Kellner, Hans. Language and Historical Representation: Getting the Story Crooked, Madison: U of Wisconsin P, 1989.

Lehman, Daniel W. Matters of Fact: Reading Nonfiction Over the Edge. Columbus: Ohio State UP, 1997.

Lennon, J. Michael. Critical Essays on Norman Mailer. Boston: G.K. Hall \& Co., 1986.

Levine, Richard. "Murder, They Wrote". New York Times Late City Final Edition. 16 Nov. 1986: SM90.

Lyotard, Jean-François. The Postmodern Condition: A Report on Knowledge. Trans. Geoff Bennigton and Brian Massumi. Minnesota: U of Minnesota P, 1988.

Mailer, Norman. The Executioner's Song. New York: Vintage International Edition, 1998.

Merljak Zdovc, Sonja. "Novi žurnalizem Toma Wolfa v ZDA in Sloveniji." Diss. Ljubljana: Faculty of Arts, 2004.

Merrill, Robert. Norman Mailer Revisited. New York: Twayne Publishers, 1992.

O'Donnell, Patrick. Latent Destinies: Cultural Paranoia and Contemporary U.S. Narrative Durham \& London: Duke UP, 2000.

Pedri, Nancy. Factual Matters: Visual Evidence in Documentary Fiction. Diss. U of Toronto, 2001.

Rayment-Pickard, Hugh. Impossible God: Derrida's Theology. Burlington: Ashgate, 2003.

Reed, Kenneth T. Truman Capote. Boston: Twayne Publishers, 1981.

Rich, Frank. "How to Cover an Election". The New York Review of Books 55.9 (2008). 5 Oct. 2009 $<$ http://www.nybooks.com/articles/21411)>.

Ricoeur, Paul. Time and Narrative. 3 vols. Trans. Kathleen McLaughlin and David Pellauer. Chicago and London: U of Chicago P, 1983-1985.

Scaggs, John. Crime Fiction. The New Critical Idiom. London \& New York: Routledge, 2005.

Sims, Michael. "We Check In With John Berendt”. BookPage.com. Aug. 1997. 29 Jan. 2007 <http:// www.bookpage.com/9708bp/firstperson1.html>.

Sims, Norman and Mark Kramer, eds. Literary Journalism: A New Collection of the Best American Nonfiction. New York: Ballantine Books, 1995.

Stone, Jonathan. "Polyphony and the Atomic Age: Bakhtin's Assimilation of an Einsteinian Universe." PMLA, Vol. 123, No. 2, March 2008: 405-421. 
Thompson, Bill. “Bill Thompson's Eye on Books”. Interview with John Berendt. 2006. 3 May 2008 $<$ http://www.eyeonbooks.com/ibp.php?ISBN=1594200580>.

Zavarzadeh, Mas'ud. The Mythopoeic Reality: Postwar American Nonfiction Novel. Chicago: U of Illinois P, 1976. 